medRxiv preprint doi: https://doi.org/10.1101/2021.01.25.21250233; this version posted January 26, 2021. The copyright holder for this preprint (which was not certified by peer review) is the author/funder, who has granted medRxiv a license to display the preprint in It is made available under a CC-BY-NC-ND 4.0 International license .

\title{
Contamination of air and surfaces in workplaces with SARS-CoV-2 virus: a systematic review
}

Cherrie $\mathrm{JW}^{1,2}$, Cherrie, MPC ${ }^{1,3}$, Davis $\mathrm{A}^{1}$, Holmes $\mathrm{D}^{1}$, Semple $\mathrm{S}^{4}$, Steinle $\mathrm{S}^{1}$, MacDonald $\mathrm{E}^{5}$, Moore $\mathrm{G}^{6}$, Loh $\mathrm{M}^{1}$

1. Institute of Occupational Medicine, Edinburgh EH14 4AP, UK.

2. Heriot Watt University, Institute of Biological Chemistry Biophysics and Bioengineering Edinburgh EH14 4AS, UK.

3. University of Edinburgh, School of Geosciences, Drummond St, Edinburgh EH8 9XP, UK.

4. University of Stirling, Institute for Social Marketing and Health, Stirling FK9 4LA, UK.

5. University of Glasgow, Institute of Health and Wellbeing, Glasgow UK.

6. National Infection Service, Public Health England, Porton Down, Salisbury SP4 0JG, UK

Corresponding author: Prof John Cherrie, Institute of Occupational Medicine, Edinburgh EH14 4AP, UK. Email: john.cherrie@iom-world.org

\section{Key messages:}

1. What is already known about this subject?

- Low level contamination of air and surfaces in hospitals with SARS-CoV-2 RNA have been reported during the Covid-19 pandemic.

- Limited data have published from non-healthcare settings.

2. What are the new findings?

- Typically, around $6 \%$ of air and surface samples in hospitals were positive for SARSCOV-2 RNA, although there is very limited data for non-healthcare settings.

- The quality of the available measurement studies is generally poor, with little consistency in the sampling and analytical methods used.

- Few studies report the concentration of SARS-CoV-2 in air or as surface loading of virus RNA, and very few studies have reported culture of the virus.

- The best estimate of typical air concentrations in health care settings is around 0.01 SARS-CoV-2 virus RNA copies $/ \mathrm{m}^{3}$

3. How might this impact on policy or clinical practice in the foreseeable future?

- There should be concerted efforts to standardise the methods used for measuring SARS-CoV-2 and other respiratory viruses in work environments.

Word count (excluding abstract, tables etc): 3441

Abstract: 232 words

Tables/Illustrations: 6

References: 46

NOTE: This preprint reports new research that has not been certified by peer review and should not be used to guide clinical practice. Key words: SARS-CoV-2, virus, aerosol, surface, fomite, hospital, transportation 
medRxiv preprint doi: https://doi.org/10.1101/2021.01.25.21250233; this version posted January 26, 2021. The copyright holder for this preprint (which was not certified by peer review) is the author/funder, who has granted medRxiv a license to display the preprint in It is made available under a CC-BY-NC-ND 4.0 International license .

\section{ABSTRACT}

Objectives This systematic review aimed to evaluate the evidence for air and surface contamination of workplace environments with SARS-CoV-2 RNA and the quality of the methods used to identify actions necessary to improve the quality of the data.

Methods We searched Web of Science and Google Scholar until $24^{\text {th }}$ December 2020 for relevant articles and extracted data on methodology and results.

Results The vast majority of data come from healthcare settings, with typically around $6 \%$ of samples having detectable concentrations of SARS-CoV-2 RNA and almost none of the samples collected had viable virus. There were a wide variety of methods used to measure airborne virus, although surface sampling was generally undertaken using nylon flocked swabs. Overall, the quality of the measurements was poor. Only a small number of studies reported the airborne concentration of SARSCoV-2 virus RNA, mostly just reporting the detectable concentration values without reference to the detection limit. Imputing the geometric mean air concentration assuming the limit of detection was the lowest reported value, suggests typical concentrations in health care settings may be around 0.01 SARS-CoV-2 virus RNA copies/m³. Data on surface virus loading per unit area were mostly unavailable. Conclusion The reliability of the reported data is uncertain. The methods used for measuring SARSCoV-2 and other respiratory viruses in work environments should be standardised to facilitate more consistent interpretation of contamination and to help reliably estimate worker exposure. 
medRxiv preprint doi: https://doi.org/10.1101/2021.01.25.21250233; this version posted January 26, 2021. The copyright holder for this preprint (which was not certified by peer review) is the author/funder, who has granted medRxiv a license to display the preprint in It is made available under a CC-BY-NC-ND 4.0 International license .

\section{INTRODUCTION}

A large-scale, global research effort has been directed at understanding the risks from Covid-19 infections and seeking successful clinical interventions to help patients. There have been almost 70,000 scientific papers published on the topic during the first 10 months of 2020 , around $2.3 \%$ of all scientific publications during this period ${ }^{a}$. Despite all this new knowledge there has been little quantitative data on the extent of exposure to SARS-CoV-2 of workers in the healthcare sector, and much debate about the best strategies to protect them from infection ${ }^{12}$. The relative contribution of different transmission routes in terms of the risk of workplace infection continues to be poorly understood ${ }^{3}$.

Viruses may be transmitted from an infected patient to healthcare workers through a number of routes: by large droplets emitted from coughs or sneezes that may splatter directly on the worker's face; from fomite transmission where the worker contacts a surface contaminated by droplet emission and then transfers virus from the surface to their nose, mouth or eyes; and finally, from aerosol transmission where fine particles containing the virus are emitted from the respiratory system of the patient, become airborne for a period and may then be inhaled by the worker. The relative importance of these three routes in determining the risk of infection is poorly understood for SARS-CoV- $2^{3}$.

In the early stages of the pandemic, the World Health Organisation (WHO) was clear that "SARS-CoV2 transmission appears to mainly be spread via droplets and close contact with infected symptomatic cases" and in most circumstances aerosol transmission was considered unlikely ${ }^{4}$. However, as knowledge of the virus has increased it has become apparent that aerosol transmission may be more important than was previously thought and some have argued that it is a major source of infection ${ }^{5}$.

\footnotetext{
a Based on 2,769,367 papers listed in WoS for 2020, and 62,478 of these with Covid or SARS-CoV-2 in any data field.
} 
medRxiv preprint doi: https://doi.org/10.1101/2021.01.25.21250233; this version posted January 26, 2021. The copyright holder for this preprint (which was not certified by peer review) is the author/funder, who has granted medRxiv a license to display the preprint in It is made available under a CC-BY-NC-ND 4.0 International license .

The situation is further complicated because our understanding of the extent of SARS-CoV-2 air and surface contamination in hospitals and other workplaces is limited. There are only around $0.06 \%$ of all the Covid-19 related research papers that describe measurements of environmental contamination ${ }^{b}$, and these data tend not to have been appropriately summarised. Without an evidence base to understand how exposure or transmission takes place it is difficult to set out rational plans to control SARS-CoV-2 in the workplace. For example, this has resulted in heated policy debates about whether it is necessary to wear effective respiratory protection when there are no deliberate aerosol generating procedures on Covid-19 patients. It is also likely that the relative importance of different transmission routes will vary depending on the workplace, the tasks being performed and the interaction with an infective source.

The aim of this review is to summarise the reported SARS-CoV-2 RNA air and surface contamination concentrations in workplace settings where the virus is present, particularly considering the quality of the methods used, to draw lessons for future methodological developments.

\section{METHODS}

We searched Web of Science (WoS) using the terms in the title ((SARS-CoV-2 or "severe acute respiratory syndrome") and air), and ((SARS-CoV-2 or "severe acute respiratory syndrome") and surface), for all languages and all document types. In addition, we searched the Google Scholar database for the above search terms, excluding the phrase "severe acute respiratory syndrome" to restrict the hits to a manageable number. The references were combined into a single database and duplicate entries were removed. The entries were then screened by a single researcher (Cherrie, JW) on the basis of title and abstract to identify informative papers containing data on either air or surface concentrations of SARS-CoV-2 RNA in workplaces, including papers that reported their results as either

\footnotetext{
${ }^{b}$ Based on the papers reviewed here related to the 62,478 papers in WoS with Covid or SARS-CoV-2 in any data field.
} 
medRxiv preprint doi: https://doi.org/10.1101/2021.01.25.21250233; this version posted January 26, 2021. The copyright holder for this preprint (which was not certified by peer review) is the author/funder, who has granted medRxiv a license to display the preprint in It is made available under a CC-BY-NC-ND 4.0 International license .

positive or negative contamination without quantifying the extent of the contamination; papers not in the English language were excluded. Data on other measures, for example virus RNA in exhaled breath condensate, were excluded. Following the initial literature search we set up a Google Scholar alert using the same search terms as used initially. These produced periodic updates that were screened in the same way as the original citations and relevant publications were added to the final list. These periodic updates were included up to the $24^{\text {th }}$ December 2020. Copies of all papers were obtained, and data extracted into tables for summarisation. Numeric data extraction was checked by a second researcher (Steinle).

Data were summarised graphically using the DataGraph software. For datasets with more than one detectable result in a dataset of 10 or more measurements we used the elnormCensored function in in the R-package EnvStats v2.3.1 to estimate the geometric mean and associated $95 \%$ confidence intervals using the maximum likelihood method.

\section{RESULTS}

The initial WoS searches identified 44 papers relating to airborne contamination and 42 on surface contamination, some of which were included in both lists. Google Scholar produced a greater number of references: 137 on air contamination and 80 relating to surface contamination (Figure 1).

After the removal of duplicates there were 182, which resulted in 26 informative papers for inclusion in the review. A further thirteen papers were added from the ongoing literature searches or other sources and on further reading four papers were excluded: one duplicated data in another identified paper, one related to non-occupational exposure, one was not related to Covid-19 infection risks and the last was written in Persian. In the end, 35 papers were reviewed: three were available as preprints and the remainder as peer-reviewed publications (Table 1). 
medRxiv preprint doi: https://doi.org/10.1101/2021.01.25.21250233; this version posted January 26, 2021. The copyright holder for this preprint (which was not certified by peer review) is the author/funder, who has granted medRxiv a license to display the preprint in It is made available under a CC-BY-NC-ND 4.0 International license .

Fifteen of the papers were from studies undertaken in China (14 from the mainland and one from Hong Kong), nine from Europe (two from UK, four from Italy, two from Spain and one from Greece), six from North America (five from USA and one from Canada), and five from Asia (two from Singapore, two from Iran and one from Korea). All but three of the studies were carried out in hospitals, mostly in intensive care settings or isolation wards with Covid-19 patients ( $75 \%$ of the healthcare studies). The three non-healthcare papers describe measurements made on public transportation (buses in Northern Italy ${ }^{6}$ and buses and subway trains in Spain $^{7}$ ) and various workplaces in Greece (a ferryboat and a nursing home - this paper also included data for three COVID-19 isolation hospital wards and a long-term care facility where 30 asymptomatic COVID-19 cases were located $\left.{ }^{8}\right)$. Most of the studies (77\%) aimed to describe the contamination present in the setting investigated and the remainder aimed to investigate the extent of contamination in relation to patient viral load or some other patient-related factors.

There are no standardised methods used for quantification of concentrations of SARS-CoV-2 RNA in the air, and as a consequence there were many different methods used. Twenty-five of the studies involved collection of air samples: nine used gelatin filters to collect the sample, eight used wet cyclone samplers, five used impingers, six used dry filters such as PTFE, and two used a water-based condensational growth sampler; some studies used a combination of the techniques (Table 1). Only one study used a personal sampling methodology ${ }^{9}$. The remainder mostly used various combinations of area sampling close to patients (13 studies), in the background near patients (11 studies) or sampling in other areas (12 studies). The volume of air sampled using these methods varied considerably, from $0.09 \mathrm{~m}^{3}$ for a midget impinger operated for one hour, to $16 \mathrm{~m}^{3}$ for a wet cyclone operating at $400 \mathrm{l} / \mathrm{min}$ for 40 minutes. Most samples were collected over a relatively short time, typically less than one hour, and flowrates varied from 1.5 to $400 \mathrm{l} / \mathrm{min}$. 
medRxiv preprint doi: https://doi.org/10.1101/2021.01.25.21250233; this version posted January 26, 2021. The copyright holder for this preprint (which was not certified by peer review) is the author/funder, who has granted medRxiv a license to display the preprint in It is made available under a CC-BY-NC-ND 4.0 International license .

In contrast with the air sampling, there was greater consistency in the surface sampling methodologies used across the studies. There is a method published by the $\mathrm{WHO}^{10}$ that recommends samples be collected using a swab with a synthetic tip and a plastic shaft pre-moistened with viral transport medium (VTM). It is recommended that an area of $25 \mathrm{~cm}^{2}$ is swabbed, but no recommendations were made concerning the reporting of results as SARS-CoV-2 RNA per $\mathrm{cm}^{2}$. Twenty-nine papers contained data from surface sampling: 12 followed the general approach set out by the WHO and 13 used an alternative pre-moistened swab but with, for example, water, saline or phosphate buffer solution in place of VTM. The remaining studies either used dry swabs that were then transported in VTM ${ }^{11} 12,7$ or did not clearly specify the sampling approach used ${ }^{13}$.

In terms of both air and surface sampling, all of the studies used reverse transcription polymerase chain reaction (RT- PCR) analysis to detect the presence of SARS-CoV-2 virus RNA on the collection media (filter, fluid or swab). Ten of the studies attempted to culture positive samples to assess whether the virus was viable, but only one successfully cultured SARS-CoV-2; this study reported high concentrations of SARS-CoV2 RNA on all four air samples collected ${ }^{14}$. A range of gene regions were used in the RT-PCR analysis (mostly combinations of ORF1ab, RdRp, E and N genes; 8 studies used a single gene, 17 used two genes, 3 used three or more genes and 5 did not clearly specify the gene regions used in the RT-PCR analysis). There was a range of criteria used to identify positive samples based on the cycle threshold values $(\mathrm{Ct})$, which is inversely related to the amount of genome material present, with $\mathrm{Ct}<29$ representing abundant target nucleic acid in the sample and $\mathrm{Ct}$ of greater than 38 representing minimal RNA present. The criteria used in the studies to identify positive samples ranged from Ct less than 38 to 43 and in cases of multiple gene assays different strategies for identifying positive tests, e.g. replicate analysis of samples where one test was positive and the other negative. None of the studies had an adequate description of quality assurance procedures for both sample collection, e.g. calibration of airflow rates or collection of blank samples in the field, and laboratory analysis, e.g. analysis of blank and spiked samples. Only six of the studies (18\%) had any 
medRxiv preprint doi: https://doi.org/10.1101/2021.01.25.21250233; this version posted January 26, 2021. The copyright holder for this preprint (which was not certified by peer review) is the author/funder, who has granted medRxiv a license to display the preprint in It is made available under a CC-BY-NC-ND 4.0 International license .

mention of sampling quality assurance procedures and $15(44 \%)$ mentioned some details of analytical quality control.

Twenty-eight studies had contamination data from surfaces (between 5 and 1,252 swab samples) with between zero and 74\% positive (median 6\%) for SARS-CoV-2 RNA. Twenty-five studies reported air sampling data for between two and 135 samples; the proportion of samples that were positive ranged from zero to $100 \%$ with the median across all studies of $6.6 \%$ positive samples. These data are summarised in Figure 2. There were six studies that did not detect SARS-CoV-2 RNA on any air samples and five that did not detect SARS-CoV-2 on surfaces; there are no obvious differentiation between these studies and the others reported here. Four studies where less than ten air samples were collected tended to show a high proportion of positive samples (40\%-100\%) and it may be that these data are not representative of general conditions in the sampled environments.

Twenty of the studies had data for both surface and air contamination and these data are summarised in Figure 3, with the area of the data markers proportional to the number of surface samples collected. Note that the double circles represent data from two studies with the same proportion of positive samples. It is clear that in general the proportion of positive samples in a setting was similar for both air and surfaces. There are five outlier studies: four where positive samples were detected on surfaces but not in the air7,15,11 1617 and one study where a relatively high proportion of the air samples were positive but the surface samples were below the limit of detection (LOD) $)^{18}$; note this study collected less than 10 samples.

Only a small number of studies expressed the virus contamination in concentration units. Excluding studies with small numbers of samples (i.e. $<10)$, there were nine that reported air concentrations in terms of virus RNA copies per cubic meter (copies $/ \mathrm{m}^{3}$ ). Guo et $\mathrm{al}^{19}$ had the largest set of data from an intensive care unit (ICU) and a general Covid ward in Huoshenshan Hospital, Wuhan, China (120 
medRxiv preprint doi: https://doi.org/10.1101/2021.01.25.21250233; this version posted January 26, 2021. The copyright holder for this preprint (which was not certified by peer review) is the author/funder, who has granted medRxiv a license to display the preprint in It is made available under a CC-BY-NC-ND 4.0 International license .

samples obtained between 19 February and 2 March 2020, although the data were only reported as average concentrations for 16 specific locations). They used a wetted wall cyclone that collected air samples at $300 \mathrm{l} / \mathrm{min}$ over 30 -minute periods. The reported concentrations from three locations in the ICU were between 520 and 3,800 copies $/ \mathrm{m}^{3}$. However, only 4 of the 26 samples had detectable concentrations and the researchers do not describe how they treated the non-detects when taking the average and is possible that they inappropriately assumed they were zero. At the remaining sampling locations, the results were all below the detection limit, which was unspecified.

Hu et $\mathrm{a}^{13}$ provided data from various locations in the Jinyintan, Hongshan Square Cabin, and Union hospitals in Wuhan, collected between the $16^{\text {th }}$ of February to the $14^{\text {th }}$ of March 2020 . The concentrations from the positive samples ranged from 1,110 to 11,200 copies $/ \mathrm{m}^{3}$, although $89 \%$ of the measurements were below the LoD. These authors also detected SARS-CoV-2 RNA in some air samples collected outdoors near to the hospital. Data from seven other studies where more than 10 measurements were collected, showed measured air concentrations between around 1 and 8,000 RNA copies $/ \mathrm{m}^{3}$. We have either used the reported individual data points, extracted data from figures or obtained individual data points through correspondence with the authors, and used these to impute the geometric mean and $95^{\text {th }}$ percentile for each study (Figure 4). Data were available for eight studies: seven from hospital environments and one from transportation (T). In Figure 4, the squares represent the estimated geometric mean, with the size proportional to the total number of air samples. The horizontal line runs between the lower and upper confidence interval for the geometric mean and the vertical line shows the lowest reported measurement, which we assumed as the detection limit. The estimated geometric mean for the whole set of data from hospitals was 0.014 (0.0034-0.047) RNA copies/m³

Only two studies reported viral loading on surfaces in terms of RNA copies per unit area swabbed ${ }^{20,7}$; where copies were reported otherwise they were expressed per sample collected. Ma and 
medRxiv preprint doi: https://doi.org/10.1101/2021.01.25.21250233; this version posted January 26, 2021. The copyright holder for this preprint (which was not certified by peer review) is the author/funder, who has granted medRxiv a license to display the preprint in It is made available under a CC-BY-NC-ND 4.0 International license .

colleagues $^{20}$ collected 242 surface swabs in two hospitals in Beijing and found $4 \%$ were positive for SARS-CoV-2 RNA. Loading on the positive samples ranged from 7,100 to 172,000 copies $/ \mathrm{cm}^{2}$; individual results were not presented. Moreno et $\mathrm{al}^{7}$ swabbed surfaces in public transport vehicles in Barcelona. In the subway there were six of 15 swab samples categorised as positive, but for only one of the three target genes analysed. SARS-CoV-2 RNA loading ranged between 0.002 to 0.071 copies $/ \mathrm{cm}^{2}$ depending on the surface and the target. On the busses 13 of the 30 swabs were positive, mostly for just one gene. Genome loading values ranged between 0.0014 and 0.049 copies $/ \mathrm{cm}^{2}$.

\section{DISCUSSION}

The studies reviewed here were mostly descriptive and lacked a clear aim other than documenting air or surface contamination. This is perhaps unsurprising given the context of the pandemic and the need to better understand the likely routes of transmission. However, the air sampling methods employed differed greatly between studies, perhaps reflecting local availability of equipment and skills in environmental sampling and previous experience in detecting other airborne viruses, e.g. influenza. Some used methods developed for first SARS outbreak while others used methods adapted for sampling of microbiological exposures, although most air samples were obtained using high volume flowrates over relatively short durations. Almost all of the air samplers had poorly characterised aerosol aspiration efficiencies, i.e. the aerosol size range effectively collected, and cyclone devices likely only effectively sample aerosols with aerodynamic diameter more than around $1 \mu \mathrm{m}$, e.g. for the WA-400 air sampler Hu et al ${ }^{13}$ quotes a $50 \%$ aerodynamic equivalent cut-off diameter of $0.8 \mu \mathrm{m}$. However, Liu et $\mathrm{al}^{21}$, who collected three samples using a miniature cascade impactor, were able to show the potential for up to half of the SARS-CoV-2 RNA being mainly associated with aerosol with aerodynamic diameter between 0.25 and $1 \mu \mathrm{m}$ and larger than $2.5 \mu \mathrm{m}$. It is therefore possible that many of the studies underestimate the airborne virus RNA concentrations. 
medRxiv preprint doi: https://doi.org/10.1101/2021.01.25.21250233; this version posted January 26, 2021. The copyright holder for this preprint (which was not certified by peer review) is the author/funder, who has granted medRxiv a license to display the preprint in It is made available under a CC-BY-NC-ND 4.0 International license .

In situations where most of the measurements were undetectable, knowledge of the LoD is of prime importance. None of the papers reviewed here provide a clear statement of the LoD in terms of RNA copies per unit of air volume or surface area sampled. Taking the lowest reported value for the air samples, which we accept is only a crude indicator of the LoD, suggests that air concentrations from around 1 to around 2,000 copies $/ \mathrm{m}^{3}$ were measurable depending on the study. Some, but not all of this variation in the minimum reported air concentrations arises because of variation in the volume of air sampled, which typically ranged from around $0.5 \mathrm{~m}^{3}$ to about $16 \mathrm{~m}^{3}$. However, there is likely large variation in the sensitivity of the analytical techniques used, e.g. variation in the Ct cut-off value, use of one or more gene sequences for detection and repeat analysis of samples where one gene sequence was undetectable. There is no evidence that the genes used by the different assays would introduce further variation ${ }^{22}$. In clinical testing for SARS-CoV-2 virus in nasopharyngeal swabs, Arnaout et $\mathrm{a}^{23}$ noted that the LoD may vary 10,000 fold between approved test kits. Clearly, LoD affects the reporting of positive air and surface samples in the studies reviewed here.

Despite all these limitations, the available data suggests that higher levels of detectable air contamination is associated with higher surface contamination. The most likely explanation for this is that the main source of surface contamination is fine aerosol rather than droplet spray or transfer from the hands of workers or patients. In most healthcare settings the measured airborne concentrations of SARS-CoV-2 virus RNA were low, with likely geometric mean levels around 0.01 RNA copies $/ \mathrm{m}^{3}$, and the same is undoubtedly the case for surface contamination. The highest concentrations measured in healthcare settings were in excess of 10,000 RNA copies $/ \mathrm{m}^{3}$ air and around 170,000 RNA copies $/ \mathrm{cm}^{2}$ surface. Data from public transport settings are limited and there are no data on environmental contamination from other higher risk workplaces such as personal service occupations, factory workers and other non-medical essential workers ${ }^{24}$. Of course, detection of RNA does not mean that there was viable virus present, and in almost all cases the concentration in samples was too low to successfully culture virus. In the one study that successfully cultured virus from four 
medRxiv preprint doi: https://doi.org/10.1101/2021.01.25.21250233; this version posted January 26, 2021. The copyright holder for this preprint (which was not certified by peer review) is the author/funder, who has granted medRxiv a license to display the preprint in It is made available under a CC-BY-NC-ND 4.0 International license .

air samples the proportion of virus RNA that was viable ranged from $38 \%$ to $79 \%^{14}$. It is also important to understand the concentration of viable virus that may give rise to a meaningful level of transmission risk. Karimzadeh et al $^{3}$ estimated that the infective dose of SARS-CoV-19 by aerosol is around 300 virus particles, which if inhaled over a working day might correspond to an average concentration of around 30 SARS-CoV-2 particles $/ \mathrm{m}^{3}$. There is however a clear need to better understand the infective dose from environmental samples, and whether this differs by the route of intake.

There is a need to develop standardised validated air and surface sampling or analysis methodologies for SARS-CoV-2 RNA, including appropriate quality assurance procedures, to ensure a more comparable set of data across all settings. Researchers should provide detection limits for their analyses in terms of RNA per unit surface area and/or per unit volume of air, and ideally the methods should be developed to reduce the LoD to increase the proportion detectable samples. Where there are data below the LoD, authors should ideally report all of the individual measured values and the imputed geometric mean concentration and other estimated summary statistics and not just the range of detectable concentrations. Ideally, measurements of air concentrations should be representative of long-term personal exposure to inhalable aeroso ${ }^{25}$. Measurement of environmental contamination on its own does not allow a proper interpretation of the exposure of workers, which depends on their interaction with the environment through their personal behaviour. Systematic and uniform reporting of measurement contextual data, e.g. worker behaviour, personal protective equipment worn by worker, room size and ventilation and data on patient status in health and social care setting is crucial to estimation of worker exposure. Similarly, the protocol should specify where and how many samples should be collected in a work environment. International cooperation to establish and maintain such a protocol would facilitate global preparedness for the next outbreak and this task might be appropriately coordinated by the WHO. Understanding environmental transmission early is key to implementation of public health measures to slow the spread of disease throughout work and public/private settings. 
medRxiv preprint doi: https://doi.org/10.1101/2021.01.25.21250233; this version posted January 26, 2021. The copyright holder for this preprint (which was not certified by peer review) is the author/funder, who has granted medRxiv a license to display the preprint in It is made available under a CC-BY-NC-ND 4.0 International license .

\section{ACKNOWLEDGMENTS}

We are grateful to a number of our colleagues for comments on early drafts of this paper.

\section{COMPETING INTERESTS}

We have no competing interests to declare.

\section{FUNDING}

This work was carried out within a project on the Evaluation of the Effectiveness of Novel workplace interventions in protecting healthcare workers from virus infection, funded by the Scottish Chief Scientists Office (Grant no: COV/IOM/20/01). 
medRxiv preprint doi: https://doi.org/10.1101/2021.01.25.21250233; this version posted January 26, 2021. The copyright holder for this preprint (which was not certified by peer review) is the author/funder, who has granted medRxiv a license to display the preprint in It is made available under a CC-BY-NC-ND 4.0 International license .

\section{REFERENCES}

1 Semple S, Cherrie JW. Covid-19: Protecting Worker Health. Ann Work Expo Health 2020; 64(5): 461-464.

2 Cherrie JW, Loh M, Aitken RJ. Protecting healthcare workers from inhaled SARS-CoV2 virus. Occup Med (Lond) 2020; 70(5): 335-337.

3 Karimzadeh S, Bhopal R, Huy N. Review of infective dose, routes of transmission, and outcome of COVID-19 caused by the SARS-COV2 virus: comparison with other respiratory viruses. Preprints 2020, 2020070613. doi:

10.20944/preprints202007.0613.v3

4 WHO. Transmission of SARS-CoV-2: implications for infection prevention precautions. Geneva: WHO 2020.

5 Prather KA, Marr LC, Schooley RT, McDiarmid MA, Wilson ME, Milton DK. Airborne transmission of SARS-CoV-2. Science 2020; 370(6514): 303-304.

6 Di Carlo P, Chiacchiaretta P, Sinjari B et al. Air and surface measurements of SARSCoV-2 inside a bus during normal operation. PLoS One 2020; 15:e0235943.

7 Moreno T, María Pintó R, Bosch A et al. Tracing surface and airborne SARS-CoV-2 RNA inside public buses and subway trains. Environment International 2020; 147:106326. doi: 10.1016/j.envint.2020.106326.

8 Mouchtouri VA, Koureas M, Kyritsi M et al. Environmental contamination of SARSCoV-2 on surfaces, air-conditioner and ventilation systems. Int J Hyg Environ Health 2020; 230: 113599.

9 Santarpia JL, Rivera DN, Herrera VL et al. Aerosol and surface contamination of SARSCoV-2 observed in quarantine and isolation care. Sci Rep 2020; 10: 12732.

10 WHO. Surface sampling of coronavirus disease (COVID-19): A practical "how to" protocol for health care and public health professionals. Geneva: WHO 2020.

11 Cheng VC, Wong SC, Chan VW et al. Air and environmental sampling for SARS-CoV-2 around hospitalized patients with coronavirus disease 2019 (COVID-19). Infect Control Hosp Epidemiol 2020; 41(11): 1258-1265.

12 Declementi M, Godono A, Mansour I et al. Assessment of air and surfaces contamination in a COVID-19 non-Intensive Care Unit. Med Lav 2020; 111: 372-378.

13 Hu J, Lei C, Chen Z et al. Distribution of Airborne SARS-CoV-2 and possible aerosol transmission in Wuhan hospitals, China. National Science Review 2020. doi: 10.1093/nsr/nwaa250

14 Lednicky JA, Lauzardo M, Fan ZH et al. Viable SARS-CoV-2 in the air of a hospital room with COVID-19 patients. Int J Infect Dis 2020; 100: 476-482.

15 Ong SWX, Tan YK, Chia PY et al. Air, Surface Environmental, and Personal Protective Equipment Contamination by Severe Acute Respiratory Syndrome Coronavirus 2 (SARS-CoV-2) From a Symptomatic Patient. JAMA 2020; 323(16):1610-1612. doi:10.1001/jama.2020.3227.

16 Cai Y, Wu X, Zhang Y et al. Severe Acute Respiratory Syndrome Coronavirus 2 (SARSCoV-2) Contamination in Air and Environment in Temporary COVID-19 ICU Wards. Research Square Preprints 2020. DOI: 10.21203/rs.3.rs-21384/v1.

17 Li YH, Fan YZ, Jiang L, Wang HB. Aerosol and environmental surface monitoring for SARS-CoV-2 RNA in a designated hospital for severe COVID-19 patients. Epidemiol Infect 2020; 148: e154. 
medRxiv preprint doi: https://doi.org/10.1101/2021.01.25.21250233; this version posted January 26, 2021. The copyright holder for this preprint (which was not certified by peer review) is the author/funder, who has granted medRxiv a license to display the preprint in It is made available under a CC-BY-NC-ND 4.0 International license .

18 Jin T, Li J, Yang J et al. SARS-CoV-2 presented in the air of an intensive care unit (ICU). Sustain Cities Soc 2020: 102446.

19 Guo ZD, Wang ZY, Zhang SF et al. Aerosol and Surface Distribution of Severe Acute Respiratory Syndrome Coronavirus 2 in Hospital Wards, Wuhan, China, 2020. Emerg Infect Dis 2020; 26(7):1583-1591. https://dx.doi.org/10.3201/eid2607.200885.

20 Ma J, Qi X, Chen $\mathrm{H}$ et al. COVID-19 patients in earlier stages exhaled millions of SARSCoV-2 per hour. Clin Infect Dis 2020. doi: 10.1093/cid/ciaa1283.

21 Liu Y, Ning Z, Chen Y et al. Aerodynamic analysis of SARS-CoV-2 in two Wuhan hospitals. Nature 2020; 582: 557-560.

22 Vogels CBF, Brito AF, Wyllie AL et al. Analytical sensitivity and efficiency comparisons of SARS-CoV-2 RT-qPCR primer-probe sets. Nat Microbiol 2020; 5: 1299-1305.

23 Arnaout R, Lee RA, Lee GR et al. SARS-CoV2 Testing: The Limit of Detection Matters. bioRxiv 2020. doi: 10.1101/2020.06.02.131144.

24 Mutambudzi M, Niedwiedz C, Macdonald EB et al. Occupation and risk of severe COVID-19: prospective cohort study of 120075 UK Biobank participants.

Occupational and Environmental Medicine 2020. http://dx.doi.org/10.1136/oemed2020-106731.

25 Kenny L, Ogden T. Twenty-five years of inhalable dust. The Annals of Occupational Hygiene 2000; 44: 561-563.

26 Bloise I, Gomez-Arroyo B, Garcia-Rodriguez J, Group SA-C-W. Detection of SARS-CoV2 on high-touch surfaces in a clinical microbiology laboratory. J Hosp Infect 2020; 105: 784-786.

27 Chia PY, Coleman KK, Tan YK et al. Detection of air and surface contamination by SARS-CoV-2 in hospital rooms of infected patients. Nat Commun 2020; 11: 2800.

28 Colaneri $M$, Seminari $E$, Novati $S$ et al. Severe acute respiratory syndrome coronavirus 2 RNA contamination of inanimate surfaces and virus viability in a health care emergency unit. Clin Microbiol Infect 2020; 26: 1094 e1-1094 e5.

29 Faridi S, Niazi S, Sadeghi $K$ et al. A field indoor air measurement of SARS-CoV-2 in the patient rooms of the largest hospital in Iran. Science of The Total Environment 2020; 725. https://doi.org/10.1016/j.scitotenv.2020.138401.

30 Horve PF, Dietz L, Fretz $M$ et al. Identification of SARS-CoV-2 RNA in Healthcare Heating, Ventilation, and Air Conditioning Units. medRxiv 2020. https://doi.org/10.1101/2020.06.26.20141085.

31 Jan I, Chen K, Sayan M et al. Prevalence of Surface Contamination With SARS-CoV-2 in a Radiation Oncology Clinic. JAMA Oncol 2020; 6(10):1632-1634.

32 Kenarkoohi A, Noorimotlagh Z, Falahi S et al. Hospital indoor air quality monitoring for the detection of SARS-CoV-2 (COVID-19) virus. Sci Total Environ 2020; 748:

141324.

33 Lednicky JA, Shankar SN, Elbadry MA et al. Collection of SARS-CoV-2 Virus from the Air of a Clinic within a University Student Health Care Center and Analyses of the Viral Genomic Sequence. Aerosol and Air Quality Research 2020; 20: 1167-1171.

34 Liu Y, Ning Z, Chen Y et al. Aerodynamic Characteristics and RNA Concentration of SARS-CoV-2 Aerosol in Wuhan Hospitals during COVID-19 Outbreak: bioRxiv 2020. https://doi.org/10.1101/2020.03.08.982637.

35 Moore G, Rickard H, Stevenson D et al. Detection of SARS-CoV-2 within the healthcare environment: a multicentre study conducted during the first wave of the 
medRxiv preprint doi: https://doi.org/10.1101/2021.01.25.21250233; this version posted January 26, 2021. The copyright holder for this preprint (which was not certified by peer review) is the author/funder, who has granted medRxiv a license to display the preprint in It is made available under a CC-BY-NC-ND 4.0 International license .

COVID-19 outbreak in England. medRxiv 2020. https://doi.org/10.1101/2020.09.24.20191411.

36 Razzini K, Castrica M, Menchetti L et al. SARS-CoV-2 RNA detection in the air and on surfaces in the COVID-19 ward of a hospital in Milan, Italy. Sci Total Environ 2020; 742: 140540.

37 Shin KS, Park HS, Lee J, Lee JK. Environmental surface testing for severe acute respiratory syndrome coronavirus 2 (SARS-CoV-2) during prolonged isolation of an asymptomatic carrier. Infect Control Hosp Epidemiol 2020:1-3. doi: 10.1017/ice.2020.300

38 Tan L, Ma B, Lai X et al. Air and surface contamination by SARS-CoV-2 virus in a tertiary hospital in Wuhan, China. Int J Infect Dis 2020; 99: 3-7.

39 Wang J, Feng $\mathrm{H}$, Zhang $\mathrm{S}$ et al. SARS-CoV-2 RNA detection of hospital isolation wards hygiene monitoring during the Coronavirus Disease 2019 outbreak in a Chinese hospital. Int J Infect Dis 2020; 94: 103-106.

40 Wang Y, Qiao F, Zhou F, Yuan Y. Surface distribution of severe acute respiratory syndrome coronavirus 2 in Leishenshan Hospital in China. Indoor and Built Environment 2020. https://doi.org/10.1177/1420326X20942938

41 Wu S, Wang Y, Jin X, Tian J, Liu J, Mao Y. Environmental contamination by SARS-CoV2 in a designated hospital for coronavirus disease 2019. Am J Infect Control 2020; 48: 910-914.

42 Ye G, Lin $\mathrm{H}$, Chen $\mathrm{S}$ et al. Environmental contamination of SARS-CoV-2 in healthcare premises. J Infect 2020; 81: e1-e5.

43 Zhou J, Otter JA, Price JR et al. Investigating SARS-CoV-2 surface and air contamination in an acute healthcare setting during the peak of the COVID-19 pandemic in London. Clin Infect Dis 2020. DOI: 10.1093/cid/ciaa905.

44 Zhou L, Yao M, Zhang X et al. Breath-, air- and surface-borne SARS-CoV-2 in hospitals. J Aerosol Sci 2020: 105693.

45 Lei $H, Y$, F, Liu X et al. SARS-CoV-2 environmental contamination associated with persistently infected COVID-19 patients. Influenza Other Respir Viruses 2020; 14: 688-699.

46 Dumont-Leblond N, Veillette M, Mubareka S et al. Low incidence of airborne SARSCoV-2 in acute care hospital rooms with optimized ventilation. Emerg Microbes Infect 2020; 9(1): 2597-2605. doi: 10.1080/22221751.2020.1850184. 
Table 1: Summary of studies reviewed: setting, study aims and methodology

\begin{tabular}{|c|c|c|c|c|c|c|c|c|c|c|}
\hline $\begin{array}{l}\text { Stud } \\
\text { y No. }\end{array}$ & Authors & Country & Setting & Location & $\begin{array}{l}\mathrm{Ai} \\
\mathrm{m}\end{array}$ & $\begin{array}{c}\text { Air } \\
\text { samplin } \\
\text { g } \\
\text { method }\end{array}$ & $\begin{array}{c}\text { Air } \\
\text { samplin } \\
\mathbf{g} \\
\text { strategy }\end{array}$ & $\begin{array}{l}\text { Surface } \\
\text { samplin } \\
\text { g } \\
\text { method }\end{array}$ & $\begin{array}{l}\text { Definition } \\
\text { of positive } \\
\text { in RT-PCR } \\
\text { analysis }\end{array}$ & $\begin{array}{l}\text { Genes } \\
\text { analysed }\end{array}$ \\
\hline 1 & Bloise et $\mathrm{al}^{26}$ & Spain & $\begin{array}{l}\text { Hospital } \\
\text { Universitari } \\
\text { o La Paz, } \\
\text { Madrid }\end{array}$ & $\begin{array}{l}\text { Microbiology } \\
\text { laboratory } \\
\text { used for SARS- } \\
\text { CoV-2 } \\
\text { diagnosis }\end{array}$ & $\mathrm{D}$ & - & - & WHO & $\begin{array}{l}\text { Any of the } \\
\text { three genes } \\
\mathrm{Ct}<39\end{array}$ & $\begin{array}{l}\text { ORF1ab, N } \\
\text { and S genes }\end{array}$ \\
\hline 2 & Cai et al ${ }^{16}$ & China & $\begin{array}{l}\text { Tongji } \\
\text { Hospital, } \\
\text { Tongji } \\
\text { Medical } \\
\text { College, } \\
\text { Wuhan }\end{array}$ & $\begin{array}{l}\text { Four } \\
\text { temporary } \\
\text { COVID-19 ICU } \\
\text { wards }\end{array}$ & $\mathrm{D}$ & DF & $\mathrm{U}$ & WHO & $\begin{array}{l}\text { Ct } \leq 38 \text { (not } \\
\text { clear } \\
\text { whether } \\
\text { just one } \\
\text { gene or } \\
\text { both) }\end{array}$ & $\begin{array}{l}\text { ORF1a/b } \\
\text { and RdRp } \\
\text { genes }\end{array}$ \\
\hline 3 & Cheng et $\mathrm{al}^{11}$ & $\begin{array}{l}\text { Hong } \\
\text { Kong }\end{array}$ & $\begin{array}{l}\text { Queen Mary } \\
\text { Hospital }\end{array}$ & $\begin{array}{l}\text { Patients } \\
\text { hospitalized } \\
\text { singly in } \\
\text { airborne } \\
\text { infection } \\
\text { isolation } \\
\text { rooms }\end{array}$ & $A$ & GF & $T$ & Dry & Not clear & $\begin{array}{l}\text { RdRp and } \\
\text { helicase } \\
\text { (Hel) }\end{array}$ \\
\hline 4 & Chia et $a^{27}$ & $\begin{array}{l}\text { Singapor } \\
\text { e }\end{array}$ & $\begin{array}{l}\text { National } \\
\text { Centre for } \\
\text { Infectious } \\
\text { Diseases, } \\
\text { Singapore }\end{array}$ & $\begin{array}{l}\text { Three } \\
\text { airborne } \\
\text { infection } \\
\text { isolation } \\
\text { rooms in the } \\
\text { ICU and } 27\end{array}$ & $A$ & $\mathrm{Im}$ & $A P+A B$ & OW & $\begin{array}{l}\text { Positive } \\
\text { detection } \\
\text { was } \\
\text { recorded as } \\
\text { long as } \\
\text { amplication }\end{array}$ & $\begin{array}{l}\text { ORF1ab and } \\
\text { E genes }\end{array}$ \\
\hline
\end{tabular}




\begin{tabular}{|c|c|c|c|c|c|c|c|c|c|c|}
\hline & & & & $\begin{array}{l}\text { rooms in the } \\
\text { general ward }\end{array}$ & & & & & $\begin{array}{l}\text { was } \\
\text { observed in } \\
\text { at least one } \\
\text { assay. }\end{array}$ & \\
\hline 5 & Colaneri et al ${ }^{28}$ & Italy & $\begin{array}{l}\text { Hospital in } \\
\text { Pavia }\end{array}$ & $\begin{array}{l}\text { Infectious } \\
\text { diseases } \\
\text { emergency } \\
\text { unit and pre- } \\
\text { intensive care } \\
\text { ward }\end{array}$ & $\mathrm{D}$ & - & - & WHO & Not clear & $\begin{array}{l}\text { RdRp and } \mathrm{E} \\
\text { genes }\end{array}$ \\
\hline 6 & Di Carlo et al $^{6}$ & Italy & $\begin{array}{l}\text { Electric bus } \\
\text { line in Chieti }\end{array}$ & & $\mathrm{D}$ & GF & $A B$ & OW & $\begin{array}{l}\text { at least two } \\
\text { genes with } \\
\mathrm{Ct}<37\end{array}$ & $\begin{array}{l}\text { ORF1ab, N } \\
\text { and S genes }\end{array}$ \\
\hline 7 & Faridi et $\mathrm{al}^{29}$ & Iran & $\begin{array}{l}\text { Imam } \\
\text { Khomeini } \\
\text { Hospital } \\
\text { Complex, } \\
\text { Tehran }\end{array}$ & ICU & $\mathrm{D}$ & $\mathrm{Im}$ & $A B$ & - & $\begin{array}{l}\text { Ct }<38 \\
\text { (unclear if } \\
\text { one or two } \\
\text { genes) }\end{array}$ & $\begin{array}{l}\text { RdRp and } \mathrm{E} \\
\text { genes }\end{array}$ \\
\hline 8 & Guo et al ${ }^{19}$ & China & $\begin{array}{l}\text { ICU and } \\
\text { General } \\
\text { Covid ward } \\
\text { in } \\
\text { Huoshensha } \\
\text { n Hospital, } \\
\text { Wuhan }\end{array}$ & ICU & $\mathrm{D}$ & WC & 0 & WHO & $\begin{array}{l}\text { Either gene } \\
\text { had } \mathrm{Ct}<40 \\
\text { (weak } \\
\text { positive) or } \\
\text { both (strong } \\
\text { positive) }\end{array}$ & $\begin{array}{l}\text { ORF1ab and } \\
\text { nucleocapsi } \\
\text { d protein } \\
\text { (NP) gene }\end{array}$ \\
\hline 9 & Horve et $\mathrm{al}^{30}$ & USA & $\begin{array}{l}\text { Oregon } \\
\text { Health and } \\
\text { Science } \\
\text { University } \\
\text { hospital }\end{array}$ & $\begin{array}{l}\text { Ventilation air } \\
\text { handling units }\end{array}$ & $\mathrm{D}$ & - & - & WHO & Not clear & $\begin{array}{l}157 \text { bp } \\
\text { segment of } \\
\text { the SARS- } \\
\text { CoV-2 spike }\end{array}$ \\
\hline
\end{tabular}




\begin{tabular}{|c|c|c|c|c|c|c|c|c|c|c|}
\hline & & & & & & & & & & $\begin{array}{l}\text { glycoprotei } \\
\text { n gene }\end{array}$ \\
\hline 10 & Hu et $\mathrm{al}^{13}$ & China & $\begin{array}{l}\text { Jinyintan, } \\
\text { Hongshan } \\
\text { Square } \\
\text { Cabin, and } \\
\text { Union } \\
\text { hospitals in } \\
\text { Wuhan }\end{array}$ & $\begin{array}{l}\text { ICU, CT area, } \\
\text { staff areas and } \\
\text { hallway. }\end{array}$ & D & WC & $A P+O$ & $\begin{array}{l}\text { Not } \\
\text { Spec }\end{array}$ & $\begin{array}{l}\mathrm{Ct}<40 \\
\text { (ORF1ab, } \\
\text { confirmed } \\
\text { with } \mathrm{N} \text { gene } \\
\text { for } \mathrm{Ct} \\
\text { values } \\
\text { between } 37 \\
\text { and 40) }\end{array}$ & $\begin{array}{l}\text { ORF1ab, } \\
\text { confirmed } \\
\text { with N gene }\end{array}$ \\
\hline 11 & Jan et $\mathrm{al}^{31}$ & USA & $\begin{array}{l}\text { COVID-19 } \\
\text { referral } \\
\text { center in } \\
\text { New Jersey }\end{array}$ & $\begin{array}{l}\text { Patient areas, } \\
\text { staff areas and } \\
\text { departmental } \\
\text { equipment }\end{array}$ & D & - & - & WHO & $\begin{array}{l}\text { Ct }<40 \text { (not } \\
\text { clear if both } \\
\text { genes) }\end{array}$ & $\begin{array}{l}\text { ORF1ab and } \\
\text { E genes }\end{array}$ \\
\hline 12 & Jin et $a l^{18}$ & China & $\begin{array}{l}\text { Jiangjunsha } \\
\text { n Hospital in } \\
\text { Guizhou }\end{array}$ & ICU & $A$ & WC & $A P+O$ & WHO & $\begin{array}{l}\text { Ct }<40 \text { in } \\
\text { either gene } \\
=\text { positive } \\
\text { and both } \\
\text { genes = } \\
\text { intensly } \\
\text { positive }\end{array}$ & $\begin{array}{l}\text { ORF1ab and } \\
\text { NP genes }\end{array}$ \\
\hline 13 & Kenarkoohi et al ${ }^{32}$ & Iran & $\begin{array}{l}\text { Shahid } \\
\text { Mustafa } \\
\text { Khomeini } \\
\text { Hospital }\end{array}$ & $\begin{array}{l}\text { ICU and other } \\
\text { areas of the } \\
\text { hospital }\end{array}$ & D & $\operatorname{Im}$ & $A B$ & - & $\begin{array}{l}\mathrm{Ct}<40 \text { (not } \\
\text { clear if both } \\
\text { genes) }\end{array}$ & $\begin{array}{l}\text { ORF1ab and } \\
N \text { genes }\end{array}$ \\
\hline 14 & Lednicky et al $\left.\right|^{33}$ & USA & $\begin{array}{l}\text { A clinic } \\
\text { within a } \\
\text { university } \\
\text { student }\end{array}$ & $\begin{array}{l}\text { In a hallway, } \\
\text { approximately } \\
3 \text { meters from } \\
\text { nearest } \\
\text { patient traffic. }\end{array}$ & D & CG & 0 & - & Not clear & $\mathrm{N}$ gene \\
\hline
\end{tabular}




\begin{tabular}{|c|c|c|c|c|c|c|c|c|c|c|}
\hline & & & $\begin{array}{l}\text { health care } \\
\text { center }\end{array}$ & & & & & & & \\
\hline 15 & Lednicky et al $\left.\right|^{14}$ & USA & $\begin{array}{l}\text { University of } \\
\text { Florida } \\
\text { Health, } \\
\text { Shands } \\
\text { Hospital, } \\
\text { Gainesville, } \\
\text { Florida }\end{array}$ & $\begin{array}{l}\text { Designated } \\
\text { COVID-19 } \\
\text { ward }\end{array}$ & $\mathrm{D}$ & CG & $A B$ & - & Ct $<39.15$ & $\mathrm{~N}$ gene \\
\hline 16 & Li et al ${ }^{17}$ & China & $\begin{array}{l}\text { Union } \\
\text { Hospital, } \\
\text { Tongji } \\
\text { Medical } \\
\text { College, } \\
\text { Huazhong } \\
\text { University of } \\
\text { Science and } \\
\text { Technology }\end{array}$ & $\begin{array}{l}\text { ICU ward, } \\
\text { general } \\
\text { isolation } \\
\text { wards, fever } \\
\text { clinic and } \\
\text { other areas }\end{array}$ & $\mathrm{D}$ & $\mathrm{Im}$ & $A P+A B$ & OW & $\begin{array}{l}\text { Ct of less } \\
\text { than } 37 \\
\text { denoted } \\
\text { positive } \\
\text { findings. A } \\
\text { Ct of } \\
\text { greater } \\
\text { than } 37 \text { was } \\
\text { subjected to } \\
\text { retesting. }\end{array}$ & $\begin{array}{l}\text { Not } \\
\text { specified }\end{array}$ \\
\hline 17 & Liu et $\mathrm{al}^{34}$ & China & $\begin{array}{l}\text { Renmin } \\
\text { Hospital of } \\
\text { Wuhan } \\
\text { University }\end{array}$ & $\begin{array}{l}\text { Field hospital } \\
\text { and ICU, plus } \\
\text { public areas. }\end{array}$ & $\mathrm{D}$ & GF & $A B$ & - & $\begin{array}{l}\mathrm{Ct}>40 \text { (not } \\
\text { clear if both } \\
\text { genes) }\end{array}$ & $\begin{array}{l}\text { ORF1ab and } \\
N \text { genes }\end{array}$ \\
\hline 18 & Ma et $a^{20}$ & China & $\begin{array}{l}\text { Two } \\
\text { hospitals in } \\
\text { Beijing }\end{array}$ & $\begin{array}{l}\text { Covid wards, } \\
\text { quarantine } \\
\text { hotels, homes }\end{array}$ & $A$ & WC & $\begin{array}{c}A P+A B \\
+0\end{array}$ & OW & $\begin{array}{l}\text { Ct values of } \\
\text { less than } 37 \\
\text { or those } \\
\text { detected } \\
\text { with a } \mathrm{Ct} \\
\text { value of } 37- \\
40 \text { along }\end{array}$ & $\begin{array}{l}\text { ORF1ab and } \\
N \text { genes }\end{array}$ \\
\hline
\end{tabular}




\begin{tabular}{|c|c|c|c|c|c|c|c|c|c|c|}
\hline & & & & & & & & & $\begin{array}{l}\text { with an "S" } \\
\text { shaped } \\
\text { amplificatio } \\
\text { n curve. }\end{array}$ & \\
\hline 19 & Moore et $\mathrm{al}^{35}$ & UK & $\begin{array}{l}\text { Eight acute } \\
\text { hospital } \\
\text { trusts in } \\
\text { England }\end{array}$ & $\begin{array}{l}\text { Negative } \\
\text { pressure } \\
\text { isolation } \\
\text { rooms }\end{array}$ & A & WC / GF & AP & WHO & $\begin{array}{l}\text { Amplificatio } \\
\text { n detected } \\
\text { in both } \\
\text { replicates. } \\
\text { Suspect } \\
\text { samples } \\
\text { were re- } \\
\text { analysed. }\end{array}$ & $\begin{array}{l}\text { ORF1ab, } \\
\text { RdRp, E, N } \\
\text { genes }\end{array}$ \\
\hline 20 & Mouchtouri et al ${ }^{8}$ & Greece & $\begin{array}{l}\text { Various } \\
\text { settings }\end{array}$ & $\begin{array}{l}\text { A ferryboat, a } \\
\text { nursing home } \\
\text { and three } \\
\text { COVID-19 } \\
\text { isolation } \\
\text { hospital wards }\end{array}$ & $\mathrm{D}$ & GF & $A B+O$ & WHO & Not clear & E gene \\
\hline 21 & Ong et $a^{15}$ & $\begin{array}{l}\text { Singapor } \\
\text { e }\end{array}$ & $\begin{array}{l}\text { Outbreak } \\
\text { center in } \\
\text { Singapore }\end{array}$ & Isolation ward & $\mathrm{D}$ & $\mathrm{DF} / \mathrm{GF}$ & $\begin{array}{c}A P+A B \\
+O\end{array}$ & OW & Not clear & $\begin{array}{l}\text { E gene, } \\
\text { although } \\
\text { not clear }\end{array}$ \\
\hline 22 & Razzini et $a^{36}$ & Italy & $\begin{array}{l}\text { Hospital in } \\
\text { Milan }\end{array}$ & Covid ward & $D$ & GF & $\begin{array}{c}A P+A B \\
+O\end{array}$ & OW & $\mathrm{Ct}<40$ & Unclear \\
\hline 23 & Santarpia et al ${ }^{9}$ & USA & $\begin{array}{l}\text { University of } \\
\text { Nebraska } \\
\text { Medical } \\
\text { Center }\end{array}$ & $\begin{array}{l}\text { Hospital } \\
\text { Biocontainme } \\
\text { nt Unit and } \\
\text { National } \\
\text { Quarantine } \\
\text { Unit }\end{array}$ & $\mathrm{D}$ & GF & $A P+P$ & OW & $\mathrm{Ct}<39.2$ & E gene \\
\hline
\end{tabular}




\begin{tabular}{|c|c|c|c|c|c|c|c|c|c|c|}
\hline 24 & Shin et $\mathrm{al}^{37}$ & Korea & $\begin{array}{l}\text { Chungbuk } \\
\text { National } \\
\text { University } \\
\text { Hospital }\end{array}$ & $\begin{array}{l}\text { Mother and } \\
\text { daughter in a } \\
\text { community } \\
\text { treatment } \\
\text { centre }\end{array}$ & $A$ & - & - & OW & $\begin{array}{l}\mathrm{Ct}<40 \text { for } \\
\text { all three } \\
\text { genes }\end{array}$ & $\begin{array}{l}\text { RdRp, } \mathrm{N} \\
\text { and E genes }\end{array}$ \\
\hline 25 & Tan et $\left.a\right|^{38}$ & China & $\begin{array}{l}\text { Tongji } \\
\text { Hospital, } \\
\text { Huazhong } \\
\text { University of } \\
\text { Science and } \\
\text { Technology }\end{array}$ & $\begin{array}{l}\text { Isolation } \\
\text { wards and the } \\
\text { intensive care } \\
\text { unit (ICU) }\end{array}$ & $D$ & $\mathrm{DF}$ & $A P+O$ & ow & Not clear & ORF1ab \\
\hline 26 & Wang et $\mathrm{al}^{39}$ & China & $\begin{array}{l}\text { First } \\
\text { Affiliated } \\
\text { Hospital of } \\
\text { Zhejiang } \\
\text { University }\end{array}$ & $\begin{array}{l}\text { Hospital } \\
\text { isolation and } \\
\text { ICU }\end{array}$ & $\mathrm{D}$ & - & - & WHO & $\mathrm{Ct}<40$ & $\begin{array}{l}\text { Not } \\
\text { specified }\end{array}$ \\
\hline 27 & Wang et $\mathrm{al}^{40}$ & China & $\begin{array}{l}\text { Wuhan } \\
\text { Leishenshan } \\
\text { Hospital in } \\
\text { Wuhan }\end{array}$ & $\begin{array}{l}\text { ICU and } \\
\text { general ward } \\
\text { in a field } \\
\text { hospital }\end{array}$ & $\mathrm{D}$ & - & - & OW & Not clear & $\begin{array}{l}\text { Not } \\
\text { specified }\end{array}$ \\
\hline 28 & Wu et $\mathrm{al}^{41}$ & China & $\begin{array}{l}\text { Wuhan No. } \\
7 \text { Hospital }\end{array}$ & $\begin{array}{l}\text { Hospital } \\
\text { isolation and } \\
\text { ICU }\end{array}$ & $\mathrm{D}$ & - & - & WHO & $\begin{array}{l}\text { Ct }<43 \text { (not } \\
\text { clear if both } \\
\text { genes) }\end{array}$ & $\begin{array}{l}\text { RdRp and } \mathrm{N} \\
\text { genes }\end{array}$ \\
\hline 29 & Ye et $\mathrm{al}^{42}$ & China & $\begin{array}{l}\text { Zhongnan } \\
\text { Medical } \\
\text { Center of } \\
\text { Wuhan } \\
\text { University }\end{array}$ & $\begin{array}{l}\text { Various } \\
\text { locations }\end{array}$ & $\mathrm{D}$ & - & - & OW & $\begin{array}{l}\text { Ct }<40 \text { (not } \\
\text { clear if both } \\
\text { genes) }\end{array}$ & $\begin{array}{l}\text { ORF1ab and } \\
\mathrm{N} \text { genes }\end{array}$ \\
\hline 30 & Zhou et $\mathrm{al}^{43}$ & UK & $\begin{array}{l}\text { A large } \\
\text { North West }\end{array}$ & $\begin{array}{l}\text { Various } \\
\text { locations }\end{array}$ & $\mathrm{D}$ & WC & $U$ & OW & $\begin{array}{l}\text { Duplicate } \\
\text { samples }\end{array}$ & E gene \\
\hline
\end{tabular}




\begin{tabular}{|c|c|c|c|c|c|c|c|c|c|c|}
\hline & & & $\begin{array}{l}\text { London } \\
\text { teaching } \\
\text { hospital }\end{array}$ & & & & & & $\begin{array}{l}\text { both with Ct } \\
<40.4\end{array}$ & \\
\hline 31 & Zhou et al ${ }^{44}$ & China & $\begin{array}{l}\text { Four } \\
\text { hospitals in } \\
\text { Wuhan, } \\
\text { China }\end{array}$ & $\begin{array}{l}\text { Various } \\
\text { locations }\end{array}$ & $A$ & WC & $\begin{array}{c}A P+A B \\
+O\end{array}$ & OW & $\begin{array}{l}\text { Ct }<40 \text { with } \\
\text { an "S" } \\
\text { shape } \\
\text { amplifcatio } \\
\text { n curve. }\end{array}$ & $\begin{array}{l}\text { ORF1ab and } \\
\mathrm{N} \text { genes }\end{array}$ \\
\hline 32 & Declementi et al ${ }^{12}$ & Italy & $\begin{array}{l}\text { A Trauma } \\
\text { Center in } \\
\text { Northern } \\
\text { Italy }\end{array}$ & $\begin{array}{l}\text { Non-intensive } \\
\text { care for Covid } \\
\text { patients }\end{array}$ & $\mathrm{D}$ & DF & - & Dry & Not clear & $\begin{array}{l}\text { Not } \\
\text { specified }\end{array}$ \\
\hline 33 & Lei et $\mathrm{al}^{45}$ & China & $\begin{array}{l}\text { The First } \\
\text { Affiliated } \\
\text { Hospital of } \\
\text { Guangzhou } \\
\text { Medical } \\
\text { University }\end{array}$ & $\begin{array}{l}\text { ICU and an } \\
\text { isolation ward }\end{array}$ & $A$ & $\mathrm{Im} / \mathrm{WC}$ & $A P+O$ & WHO & Not clear & $\begin{array}{l}\text { ORF1ab and } \\
\mathrm{N} \text { genes }\end{array}$ \\
\hline 34 & $\begin{array}{l}\text { Dumont-Leblond et } \\
\mathrm{al}^{46}\end{array}$ & Canada & $\begin{array}{l}\text { Institut } \\
\text { Universitair } \\
\text { e de } \\
\text { Cardiologie } \\
\text { et } \\
\text { Pneumologi } \\
\text { e de Quebec }\end{array}$ & $\begin{array}{l}\text { Acute care } \\
\text { hospital rooms }\end{array}$ & $\mathrm{D}$ & $\mathrm{DF} / \mathrm{GF}$ & AP & - & $\begin{array}{l}\text { Either gene } \\
\mathrm{Ct}<40\end{array}$ & $\begin{array}{l}\text { ORF1b and } \\
N \text { genes }\end{array}$ \\
\hline 35 & Moreno et $\mathrm{al}^{7}$ & Spain & $\begin{array}{l}\text { Public } \\
\text { transport in } \\
\text { Barcelona }\end{array}$ & $\begin{array}{l}\text { Busses and } \\
\text { the subway }\end{array}$ & $\mathrm{D}$ & DF & 0 & Dry & Not clear & $\begin{array}{l}\text { NA } \\
\text { polymerase } \\
\text { (IP2 and } \\
\text { IP4) and E } \\
\text { gene }\end{array}$ \\
\hline
\end{tabular}


Aim Codes: $D$ = descriptive; $A$ = analytic

Air sampling method: $C G$ = water-based condensational growth; $D F=$ dry filter; GF = gelatin filter; $\operatorname{Im}=$ impactor; $W C=$ wetted cyclone Air sampling strategy: $A P=$ area sample near patient; $A B=$ area sample in the background; $O=$ other location; $P=$ personal; $T=$ in tented enclosure around patient; $U$ = uncertain

Surface sampling codes: WHO = WHO method with wetted swab; OW = other wetted swab; Dry = dry swab; Not Spec - not specified 
medRxiv preprint doi: https://doi.org/10.1101/2021.01.25.21250233; this version posted January 26, 2021. The copyright holder for this preprint (which was not certified by peer review) is the author/funder, who has granted medRxiv a license to display the preprint in It is made available under a CC-BY-NC-ND 4.0 International license.

Table 2: Air and surface contamination data: number of samples collected and percent positive for SARS-CoV-2 RNA

\begin{tabular}{|c|c|c|c|c|c|c|}
\hline Study & Authors & $\begin{array}{r}\text { Location } \\
\text { code }\end{array}$ & $\begin{array}{l}\text { No air } \\
\text { samples }\end{array}$ & $\begin{array}{r}\% \\
\text { positive } \\
\text { in air }\end{array}$ & $\begin{array}{r}\text { No } \\
\text { surface } \\
\text { samples }\end{array}$ & $\begin{array}{r}\% \text { positive } \\
\text { on } \\
\text { surfaces }\end{array}$ \\
\hline 1 & Bloise et al ${ }^{26}$ & H-Other & - & - & 22 & 18 \\
\hline 2 & Cai et $\mathrm{al}^{16}$ & $\mathrm{H}-\mathrm{ICU}$ & 15 & 0 & 128 & 2 \\
\hline 3 & Cheng et al ${ }^{11}$ & $\mathrm{H}-\mathrm{IW}$ & 12 & 0 & 377 & 5 \\
\hline 4 & Chia et $\mathrm{al}^{27}$ & $\mathrm{H}-\mathrm{ICU}+\mathrm{W}$ & 3 & 66 & 245 & 24 \\
\hline 5 & Colaneri et al ${ }^{28}$ & $\mathrm{H}-\mathrm{ICU}+\mathrm{W}$ & - & - & 28 & 7 \\
\hline 6 & Di Carlo et $\mathrm{al}^{6}$ & $\mathrm{~N}-\mathrm{T}$ & 14 & 0 & $45^{*}$ & 0 \\
\hline 7 & Faridi et al ${ }^{29}$ & $\mathrm{H}-\mathrm{ICU}+\mathrm{W}$ & 10 & 0 & - & - \\
\hline 8 & Guo et al $^{19}$ & $\mathrm{H}-\mathrm{ICU}+\mathrm{W}$ & 120 & 16 & 266 & 17 \\
\hline 9 & Horve et $\mathrm{al}^{30}$ & H-Other & - & - & 56 & 25 \\
\hline 10 & Hu et $\mathrm{al}^{13}$ & $\mathrm{H}-\mathrm{ICU}+\mathrm{W}$ & 81 & 11 & 24 & 21 \\
\hline 11 & Jan et $\mathrm{al}^{31}$ & H-Other & - & - & 128 & 0 \\
\hline 12 & Jin et $\mathrm{al}^{18}$ & $\mathrm{H}-\mathrm{ICU}$ & 2 & 50 & 5 & 0 \\
\hline 13 & Kenarkoohi et al ${ }^{32}$ & $\begin{array}{r}\mathrm{H}-\mathrm{ICU}+\mathrm{W}+ \\
\text { Other }\end{array}$ & 14 & 14 & - & - \\
\hline 14 & Lednicky et al ${ }^{33}$ & H-Other & 2 & 50 & - & - \\
\hline 15 & Lednicky et al $^{14}$ & $\mathrm{H}-\mathrm{IW}$ & 4 & 100 & - & - \\
\hline 16 & Li et $\mathrm{al}^{17}$ & $\begin{array}{r}\mathrm{H}-\mathrm{ICU}+\mathrm{W}+ \\
\text { Other }\end{array}$ & 135 & 0 & 90 & 2 \\
\hline 17 & Liu et $\mathrm{al}^{34}$ & $\mathrm{H}-\mathrm{ICU}+\mathrm{W}$ & 33 & 58 & - & - \\
\hline 18 & Ma et $a 1^{20}$ & $\begin{array}{r}\mathrm{H}-\mathrm{IW}+ \\
\mathrm{N}-\mathrm{O}\end{array}$ & 26 & 4 & 242 & 5 \\
\hline 19 & Moore et al ${ }^{35}$ & $\mathrm{H}-\mathrm{ICU}+\mathrm{W}$ & 89 & 4.5 & 336 & 9 \\
\hline 20 & Mouchtouri et al ${ }^{8}$ & $\begin{array}{r}\mathrm{H}+ \\
\mathrm{N}-\mathrm{T}+\mathrm{N}-\mathrm{O} \\
\end{array}$ & 12 & 8 & 77 & 18 \\
\hline 21 & Ong et $a^{15}$ & $\mathrm{H}-\mathrm{IW}$ & 6 & 0 & 28 & 61 \\
\hline 22 & Razzini et al $^{36}$ & $\mathrm{H}-\mathrm{IW}$ & 5 & 40 & 37 & 24 \\
\hline 23 & Santarpia et al ${ }^{9}$ & $\mathrm{H}-\mathrm{IW}$ & 38 & 68 & 128 & 74 \\
\hline 24 & Shin et $\mathrm{al}^{37}$ & $\mathrm{H}$-Other & - & - & 12 & 0 \\
\hline 25 & Tan et $\mathrm{al}^{38}$ & $\mathrm{H}-\mathrm{ICU}+\mathrm{W}$ & 29 & 3.4 & 355 & 3.7 \\
\hline 26 & Wang et $\mathrm{al}^{39}$ & $\mathrm{H}-\mathrm{ICU}+\mathrm{W}$ & - & - & 33 & 0 \\
\hline 27 & Wang et al ${ }^{40}$ & $\mathrm{H}-\mathrm{ICU}+\mathrm{W}$ & - & - & 66 & 4.5 \\
\hline 28 & Wu et $\mathrm{al}^{41}$ & $\mathrm{H}-\mathrm{ICU}$ & - & - & 145 & 25 \\
\hline 29 & Ye et $\mathrm{al}^{42}$ & H-Other & - & - & 1252 & 13.6 \\
\hline 30 & Zhou et al ${ }^{43}$ & H-Other & 31 & 6.4 & 218 & 10.6 \\
\hline 31 & Zhou et al ${ }^{44}$ & H-Other & 44 & 6.8 & 318 & 3.1 \\
\hline 32 & Declementi et al ${ }^{12}$ & $\mathrm{H}-\mathrm{IW}$ & 4 & 0 & 12 & 0 \\
\hline 33 & Lei et $\mathrm{al}^{45}$ & $\mathrm{H}-\mathrm{ICU}+\mathrm{W}$ & 62 & 3.2 & 338 & 0.3 \\
\hline 34 & $\begin{array}{l}\text { Dumont-Leblond } \\
\text { et } \mathrm{al}^{46}\end{array}$ & H-IW & 100 & 11 & - & - \\
\hline 35 & Moreno et $\mathrm{al}^{7}$ & $\mathrm{~N}-\mathrm{T}$ & 12 & 25 & 45 & 42 \\
\hline
\end{tabular}


medRxiv preprint doi: https://doi.org/10.1101/2021.01.25.21250233; this version posted January 26, 2021. The copyright holder for this preprint (which was not certified by peer review) is the author/funder, who has granted medRxiv a license to display the preprint in It is made available under a CC-BY-NC-ND 4.0 International license .

* 45 samples were also collected after disinfection, but these are not included in this review Location codes: $\mathrm{H}-\mathrm{ICU}=$ hospital intensive care unit; $\mathrm{H}-\mathrm{IW}=$ hospital isolation ward; $\mathrm{H}$-Other = hospital other; $\mathrm{H}-\mathrm{W}=$ hospital general ward; $\mathrm{H}-\mathrm{ICU}+\mathrm{W} ; \mathrm{H}-\mathrm{ICU}+\mathrm{W} ; \mathrm{N}-\mathrm{T}=$ non-hospital transportation 
medRxiv preprint doi: https://doi.org/10.1101/2021.01.25.21250233; this version posted January 26, 2021. The copyright holder for this preprint (which was not certified by peer review) is the author/funder, who has granted medRxiv a license to display the preprint in

It is made available under a CC-BY-NC-ND 4.0 International license.

Figures

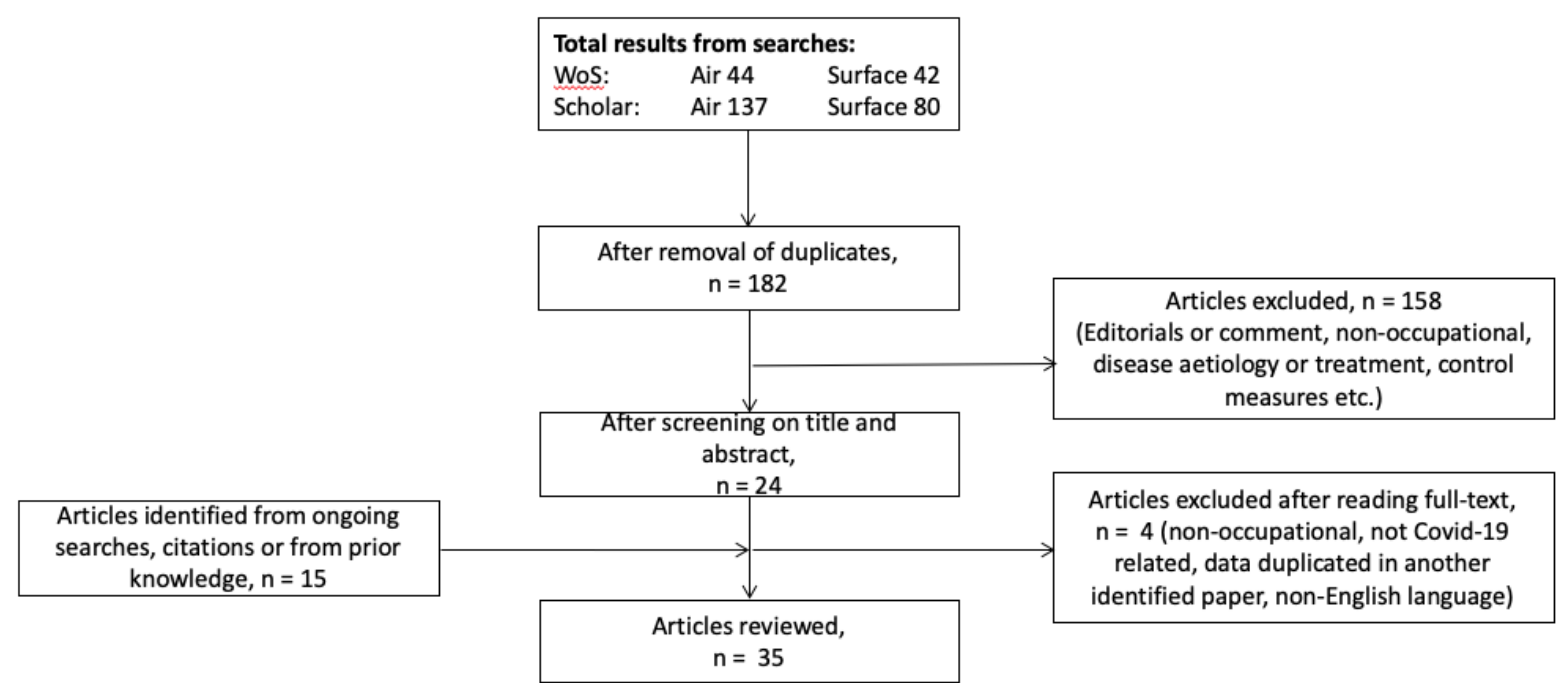

Figure 1: Results from the systematic literature search

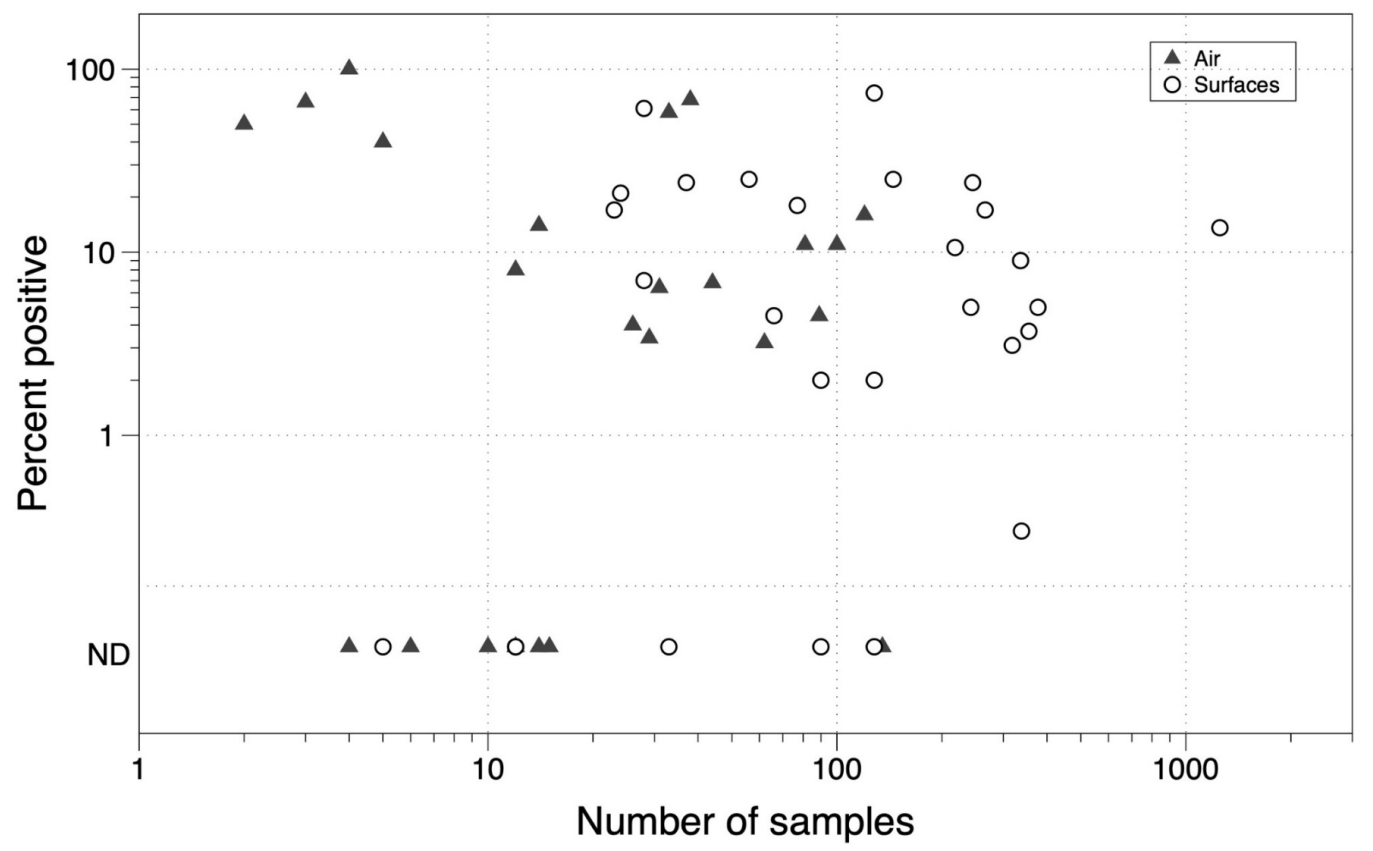

Figure 2: Scatter plot of the percentage of air and surface samples positive for SARS-CoV-2 RNA versus number of samples collected (ND = not detected) 


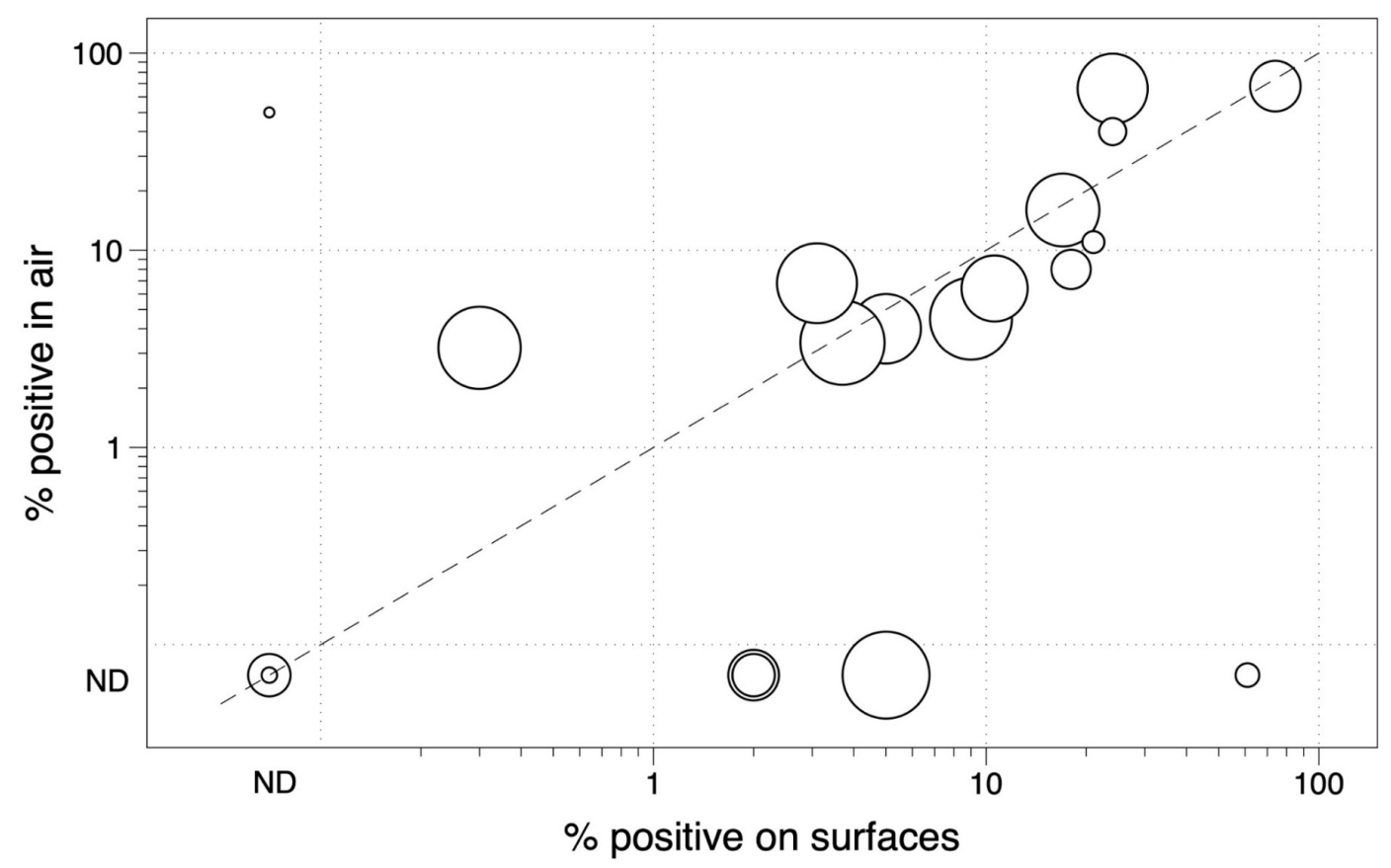

Figure 3: Scatter plot of the proportion of air and surface samples categorised as positive for studies that measured both (ND = not detected)

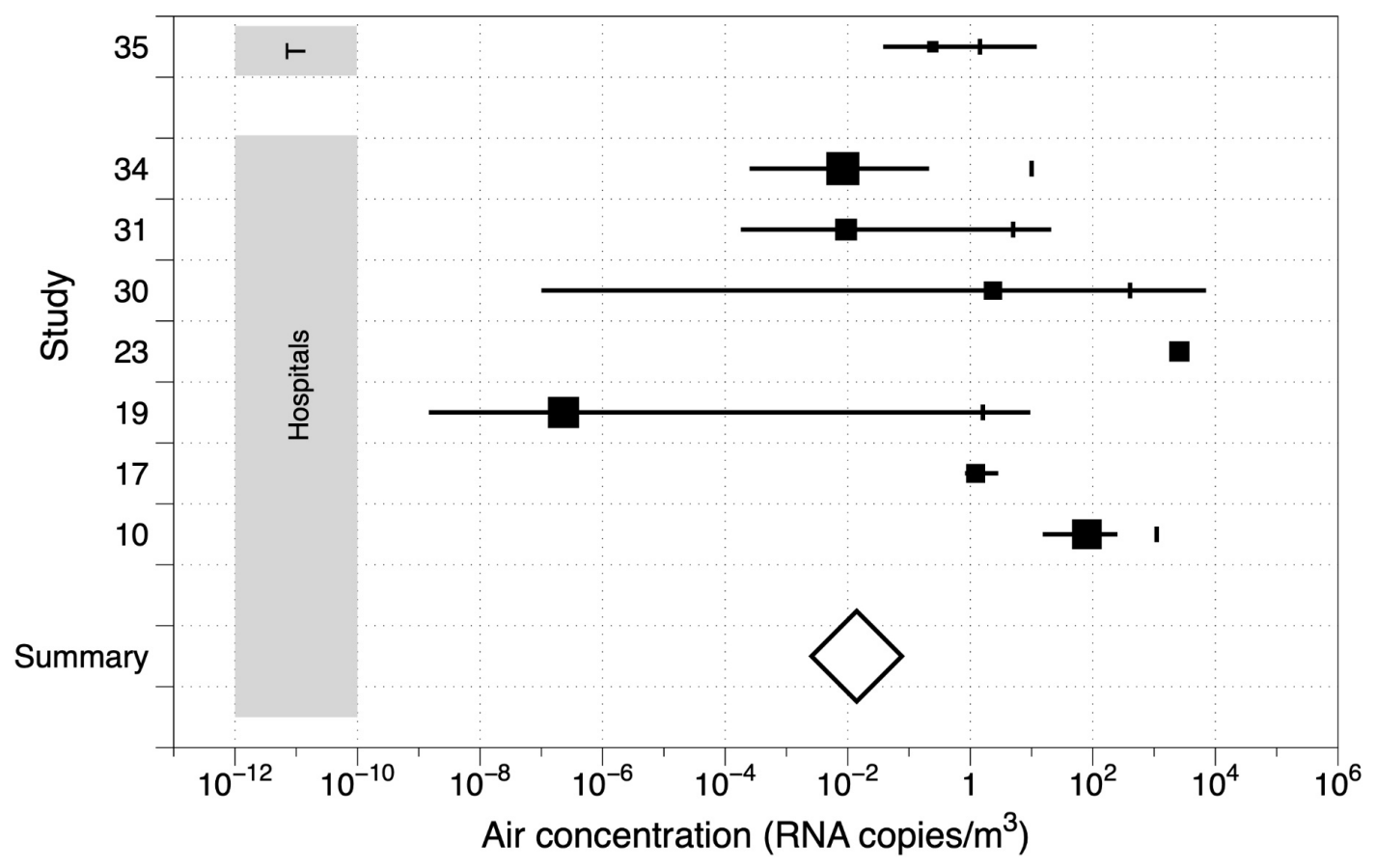

Figure 4: Imputed geometric mean SARS-CoV-2 RNA air concentrations 
medRxiv preprint doi: https://doi.org/10.1101/2021.01.25.21250233; this version posted January 26, 2021. The copyright holder for this preprint (which was not certified by peer review) is the author/funder, who has granted medRxiv a license to display the preprint in It is made available under a CC-BY-NC-ND 4.0 International license .

Note, the black squares represent the imputed geometric mean and the horizontal lines the upper and lower 95\% confidence intervals on the geometric mean. The small vertical lines are the lowest reported measurement, which was assumed to be the LoD. T = study in a transportation setting. 